DIMENSI, VOL. 8 , NO. $1: 127-141$

MARET 2019

ISSN: 2085-9996

\title{
FAKTOR-FAKTOR YANG MEMPENGARUHI PEMBERIAN KOMPENSASI PADA PEGAWAI KANTOR KECAMATAN NONGSA
}

\section{FACTORS THAT AFFECTING GIVING OF COMPENSATION IN NONGSA DISTRICT OFFICE EMPLOYEES}

\author{
Iin Indriyani ${ }^{1}$, Linayati Lestari ${ }^{2}$, Amrullah Rasal $^{3}$ \\ ${ }^{1}$ (Prodi Ilmu Pemerintahan, Fakultas Ilmu Sosial \& Ilmu Politik, Universitas Riau Kepulauan, \\ Indonesia) \\ ${ }^{2}$ (Prodi Ilmu Pemerintahan, Fakultas Ilmu Sosial \& Ilmu Politik, Universitas Riau Kepulauan, \\ Indonesia) \\ ${ }^{3}$ (Prodi Ilmu Pemerintahan, Fakultas Ilmu Sosial \& Ilmu Politik, Universitas Riau Kepulauan, \\ Indonesia) \\ Iiinindriyani@gmail.com, ${ }^{2}$ linayatilestari@yahoo.com, ${ }^{3}$ amrullahrasal67@gmail.com
}

\begin{abstract}
Abstrak
The purpose of this research is to know what factors affect the compensation. Observing the extent to which these factors affect the provision of compensation to employees in Nongsa Sub-district. As for the benefits is to be able to add insight about the theory of compensation related to the factors that influence it on the employees in the district. This research uses qualitative research method. In this research the authors use factors of compensation according to the theory of Kasmir, as for the factors that are Education, Workload and Responsibility, Position, Level Grade, and Job Performance as an indicator to determine the factors used, with data collection techniques through observation activities, interviews, and documentation.Based on the results of observations and interviews in Nongsa Sub-district, there are 5 factors that affect the compensation of Nongsa Sub-district Officials, namely: Education, Workload and Responsibility, Position, Level Grade, and Job Performance.Compensation is very important. Sub Division General and Personnel duty and responsible in the administration of public administration and personnel in the District Nongsa. The results of the study showed there are differences in the provision of Compensation between Civil Servants and Honorary Employees.
\end{abstract}

Keywords: Organization, Compensation, Compensation Factors, Human Resourses

\begin{abstract}
Tujuan dari penelitian ini adalah untuk mengetahui faktor-faktor apa sajakah yang mempengaruhi pemberian kompensasi. Mengamati sejauh mana faktor-faktor tersebut mempengaruhi pemberian kompensasi pada pegawai di Kecamatan Nongsa. Adapun manfaatnya adalah agar dapat menambah wawasan mengenai teori tentang pemberian kompensasi terkait dengan faktor-faktor yang mempengaruhinya pada pegawai di kecamatan. Penelitian ini menggunakan metode penelitian kualitatif. Dalam penelitian ini peneliti menggunakan faktor-faktor pemberian kompensasi menurut teori Kasmir, adapun faktor-faktornya yaitu: Pendidikan, Pengalaman, Beban Pekerjaan dan Tanggung Jawab, Jabatan, Jenjang Kepangkatan (Golongan), dan Prestasi Kerja sebagai indikator untuk mengetahui faktor yang digunakan, dengan teknik pengumpulan data melalui kegiatan observasi, wawancara, dan Dokumentasi. Berdasarkan hasil penelitian di Kecamatan Nongsa, diketahui bahwa terdapat 5 faktor yang mempengaruhi pemberian kompensasi pada pegawai Kecamatan Nongsa, yaitu: pendidikan, beban pekerjaan dan tanggung jawab, jabatan, jenjang kepangkatan atau golongan, dan prestasi kerja. Kompensasi merupakan hal yang sangat penting. Sub Bagian Umum dan Kepegawaian
\end{abstract}


bertugas dan bertanggung jawab dalam penyelenggaraan administrasi umum dan administrasi kepegawaian di Kecamatan Nongsa. Hasil penelitian menunjukkan terdapat perbedaan pemberian Kompensasi antara Pegawai Negeri Sipil dan Pegawai Honorer.

\section{Kata kunci: Organisasi, Kompensasi, Faktor Pemberian Kompensasi, Pegawai}

\section{PENDAHULUAN}

Salah satu kunci utama tumbuh berkembangnya sebuah organisasi adalah sumber daya manusia. Untuk mencapai tujuannya diperlukan sumber daya manusia yang berkualitas dan profesional.Dalam mengelola sumber daya manusia harus sesuai dengan norma-norma yang berlaku, yang akan memberikan rasa keadilan kepada manusia yang terlibat. Setelah melaksanakan beban dan tanggung jawabnya, tentunya pegawai memiliki hak untuk memenuhi kebutuhannya.Sesuai dengan Undang-Undang, yang mengatur tentang Aparatur Sipil Negara (ASN) dan Pegawai Negeri Sipil (PNS) adalah Undang-Undang Nomor 43 Tahun 1999 tentang perubahan atas UndangUndang Nomor 8 Tahun 1974 tentang pokok-pokok kepegawaian, dan UndangUndang Nomor 5 Tahun Tahun 2014 tentang Aparatur Sipil Negara.

Undang-Undang Nomor 5 Tahun 2014 diatur lebih spesifik tentang Aparatur Sipil Negara. Dalam Pasal 21 tentang Hak PNS, menyebutkan bahwa PNS berhak memperoleh gaji, tunjangan, fasilitas, cuti, jaminan pensiun dan jaminan hari tua, perlindungan, dan pengembangan kompetensi. Pasal 22 tentang Hak PPPK, menyebutkan bahwa PPPK berhak memperoleh gaji dan tunjangan, cuti, perlindungan, dan pengembangan kompetensi.

Berdasarkan Undang-Undang di atas telah disebutkan hal-hal yang berhak diperoleh pegawai, seperti gaji, tunjangan, jaminan, dan lain-lain. Tentunya seseorang akan mendapatkan hak nya setelah melaksanakan tanggung jawabnya. Seseorang menggunakan pengetahuan, keterampilan, tenaga, dan sebagian waktunya untuk berkarya pada suatu organisasi, dilain pihak ia mengharapkan menerima imbalan tertentu, atau yang dikenal dengan nama kompensasi.Menurut Kasmir dalam bukunya Manajemen Sumber Daya Manusia (Teori dan Paraktik) menyebutkan kompensasi 
merupakan balas jasa yang diberikan perusahaan kepada karyawannya, baik yang bersifat keuangan maupun non keuangan.

Pelaksanaan Pemerintahan Kecamatan berpedoman pada Undang-Undang Republik Indonesia. Pemerintah Daerah yang tersusun berdasarkan Undang-undang Nomor 22 Tahun 1999 tentang Pemerintahan Daerah. Undang-undang merupakan garis besar dimana teknis dan pengaturannya diserahkan pada masing individu kepada wilayah yang bersangkutan guna menuju pelayan prima pada masyarakat (Public Service) yang pada akhirnya bertujuan untuk mensejahterakan masyarakat, mencerdaskan masyarakat serta peningkatan budi pekerti masyarakat yang adil dan makmur.

Kecamatan Nongsa merupakan salah satu wilayah administrasi Kota Batam. Pemecahan atau pembagian wilayah menjadi kecamatan baru yang lebih kecil dan disesuaikan dengan perkembangan jumlah penduduk serta perkembangan sosial dan ekonomi adalah merupakan bagian upaya pemerintah untuk dapat memberikan pelayanan terbaik yang lebih mudah dan efisien, sehingga masyarakat di wilayah tersebut akan lebih mudah untuk mengurus administrasi baik hak maupun kewajiban sebagai individu, kelompok, golongan atau suatu badan usaha.

Kecamatan Nongsa terbentuk berdasarkan Undang-Undang No 53 Tahun 1999 yang ditetapkan pada tanggal 09 Oktober 1999, kemudian berdasarkan Perda No. 02 Tahun 2005. Kecamatan Nongsa terdiri dari 4 Kelurahan, yaitu:

1. Kelurahan Ngenang

2. Kelurahan Kabil

3. Kelurahan Batu Besar, dan

4. Kelurahan Sambau.

Kecamatan merupakan bagian dari pemerintahan daerah yang berhadapan langsung dengan masyarakat luas. Sebagai instansi pelayanan publik dituntut untuk memperbaiki dan senantiasa melakukan reformasi mengikuti perubahan zaman. Dalam penelitian ini menyangkut tentang kepegawaian. Pegawai merupakan salah satu pendorong agar organisasi terus berkembang. 


\section{Tabel 1 Pegawai Kecamatan Nongsa}

\begin{tabular}{|c|l|c|}
\hline No & \multicolumn{1}{|c|}{ Pegawai } & Jumlah \\
\hline 1. & Pegawai Negeri Sipil & 51 \\
\hline 2. & Tenaga Honor & 19 \\
\hline \multicolumn{2}{r}{ Total } & 70 \\
\hline
\end{tabular}

Sumber: Kantor Kecamatan Nongsa

Hal yang terjadi di lapangan yaitu mengenai naik turunnya produktivitas kerja pegawai. Tentunya banyak faktor yang mempengaruhi kinerja pegawai. Salah satunya adalah kompensasi. Gaji, yang merupakan komponen kompensasi tentunya sangat berpengaruh, akibat dari keterlambatan dan tidak tepat waktu gaji yang diberikan menyebabkan semangat kerja pegawai menurun. Dengan memberikan kompensasi, tentunya banyak hal-hal positif yang diterima organisasi dan pegawai. Pada akhirnya kompensasi akan memberikan kesejahteraan dan kebahagiaan bagu pegawai yang merupakan hak mereka seharusnya mereka terima.

Program kompensasi atau balas jasa umumnya bertujuan untuk kepentingan bersama antara organisasi atau perusahaan dan pegawai. Supaya tujuan tercapai dan memberikan kepuasan bagi semua pihak hendaknya program kompensasi ditetapkan berdasarkan prinsip adil dan wajar, undang-undang perburuhan, serta memperhatikan faktor internal dan eksternal.

Dalam mengembangkan dan menerapkan suatu sistem imbalan tertentu, kepentingan organisasi dan kepentingan pegawai mutlak perlu diperhitungkan. Kepentingan para pegawai harus mendapat perhatian dalam arti kompensasi atas jasa yang diberikan kepada organisasi harus memungkinkannya mempertahankan harkat dan martabatnya. Kompensasi tersebut memungkinkannya mempertahankan taraf hidup yang wajar dan layak untuk memenuhi kebutuhannya. Kepentingan organisasi harus terjamin dalam arti bahwa melalui pengerahan kemampuan, pengetahuan, keterampilan, waktu dan tenaga para pekerjanya, organisasi dapat mencapai tujuan dan sasarannya yang pada gilirannya memungkinkan organisasi tidak hanya sekedar mempertahankan eksistensinya, melainkan juga untuk bertumbuh dan berkembang. 


\section{METODOLOGI}

\section{Jenis Penelitian}

Penelitian ini menggunakan jenis penelitian kualititatif. Menurut Denzin dan Lincoln, penelitian kualitatif merupakan penelitian yang menggunakan latar ilmiah, dengan maksud menafsirkan fenomena yang terjadi dan dilakukan dengan jalan melibatkan berbagai metode yang ada. Penelitian kualitatif adalah suatu pendekatan penelitian yang mengungkap situasi sosial tertentu dengan mendeskripsikan kenyataan secara benar, dibentuk oleh kata-kata berdasarkan teknik pengumpulan dan analisis data yang relevan yang diperoleh dari situasi yang alamiah.

\section{Lokasi Penelitian}

Berdasarkan judul dalam penelitian ini maka peneliti dalam melakukan penelitian menentukan tempat pada Kantor Kecamatan Nongsa, di Jalan Hasanuddin, Kabil, Nongsa, Kota Batam, Kepulauan Riau.

\section{Populasi dan Sampel}

Dalam penelitian ini peneliti menggunakan Purposive random sampling, yaitu teknik pengambilan sampel dengan memperhatikan pertimbangan-pertimbangan yang dibuat oleh peneliti. Populasi pada penelitian ini yaitu pegawai yang bekerja di kantor Kecamatan Nongsa, Kota Batam. Pegawai Kecamatan Nongsa berjumlah 70 orang.Adapun yang menjadi sampel sebagai objek wawancara dalam penelitian meliputi: Camat, Sekretaris camat, Kepala Sub Bagian Umum dan Kepegawaian, Pegawai Kecamatan Nongsa 10 (Sepuluh) orang.

\section{PEMBAHASAN}

Pada organisasi, Sumber Daya Manusia ditetapkan sebagai unsur yang khusus. Dalam hal ini adalah pegawai Kecamatan Nongsa. Dianggap sebagai unsur yang khusus karena SDM baru akan terdorong untuk bekerja dan meningkatkan produktivitasnya jika beragam kebutuhannya mulai dari kebutuhan fisik (Seperti: sandang, pangan, papan), kebutuhan rasa aman, dan kebutuhan sosial terpenuhi dengan baik.Terkait dengan faktor-faktor yang mempengaruhi pemberian kompensasi, berdasarkan hasil wawancara dengan pegawai Kecamatan Nongsa diketahui bahwa 
kompensasi merupakan hal yang sangat penting. Terdapat 6 faktor yang mempengaruhi pemberian kompensasi pada pegawai.

\section{Pendidikan}

Pendidikan seseorang mempunyai peranan penting dalam organisasi. Semakin tinggi pendidikan seseorang, diharapkan semakin tinggi juga profesionelismenya dalam bekerja. Dari penelitian di Kecamatan Nongsa yang diketahui pendidikan pegawai Kecamatan sebagai berikut:

Tabel 2 Data Pendidikan Pegawai Kecamatan Nongsa

\begin{tabular}{|c|l|c|}
\hline No & \multicolumn{1}{|c|}{ Tingkat Pendidikan } & Jumlah \\
\hline 1 & SMA/SMK & 43 orang \\
\hline 3 & Sarjana (S1) & 27 orang \\
\hline \multicolumn{2}{r|}{ Jumlah } & 70 orang \\
\hline
\end{tabular}

Sumber: Bagian Pemerintahan Kecamatan Nongsa 2017

Dari tabel di atas diketahui bahwa sebanyak 27 orang pegawai Kecamatan lulus Sarjana (S1). Pada umumnya baik PNS ataupun honorer merupakan lulusan SMA/SMK sederajat sebanyak 43 orang. Sebagian diantaranya saat ini sedang melanjutkan ke jenjang sarjana. Dari penelitian diketahui bahwa bentuk kompensasi dalam bidang pendidikan adalah seperti kenaikan pangkat. Selain itu, untuk meningkatkan keterampilan pegawai juga dengan melakukan pelatihan dan perjalanan dinas. Adapun biayanya akan ditanggung oleh instansi terkait.

Pegawai lama yang sudah memiliki pengalaman bekerja tentunya berbeda dengan pegawai yang baru selesai pendidikan. Pegawai seperti ini pada umumnya belum memahami seluk-beluk pekerjaan nyata yang ada di dalam organisasi. Pegawai ini juga biasanya memiliki pengalaman kerja yang minim, karena apa yang mereka dapatkan di bangku pendidikan pada umumnya hanya teori.

Pegawai lama merasa perlu meningkatkan pendidikannya untuk kenaikan pangkat (golongan) sehingga kompensasi meningkat. Pegawai baru perlu diberikan program pengembangan SDM dan pelatihan yang berkesinambungan sehingga ia 
mampu untuk beradaptasi dan menjadi bagian penting dari organisasi yang memudahkan dan mendukungnya dengan optimal dalam bekerja.

Tingkat pendidikan sangat diperlukan oleh seorang pegawai, karena akan dapat membawa pengaruh yang terhadap dirinya sendiri maupun terhadap organisasi tempat dia bekerja. Dengan pengaruh tersebut, dapat meningkatkan semangat kerja pegawai sehingga mendapatkan kompensasi atas pekerjaan yang telah dilaksanakan. Berdasarkan hasil penelitian tersebut diketahui bahwa pendidikan berpengaruh terhadap pemberian kompensasi pada pegawai Kecamatan Nongsa.

\section{Pengalaman}

Pengalaman artinya keahlian seseorang dalam bekerja. Dari hasil penelitian diketahui bahwa pada instansi pemerintahan dan perusahaan swasta terdapat perbedaan dalam menentukan kompensasi pegawai. Pengalaman tidak termasuk dalam faktor yang mempengaruhi pemberian kompensasi pada pegawai Kecamatan Nongsa. Pengalaman dinyatakan lebih tepat untuk perusahaan swasta, karena pada perusahaan swasta keahlian pegawai sesuai bidangnya lebih diutamakan.

\section{Beban Pekerjaan dan Tanggung Jawab}

Kerja dan tanggung jawab yang diemban oleh seseorang menjadi pertimbangan untuk menentukan besar kecilnya kompensasi yang diterimanya. Artinya pegawai yang memiliki beban kerja dan tanggung jawab yang lebih besar dari yang lain tentu memiliki kompensasi yang lebih besar pula. Demikian pula sebaliknya bagi mereka yang memiliki beban kerja dan tanggung jawab yang lebih kecil maka kompensasinya juga relatif lebih rendah.

Kecamatan mempunyai tugas melaksanakan melaksanakan kewenangan pemerintahan yang dilimpahkan oleh Walikota untuk menangani sebagian urusan otonomi daerah. Setiap bagian dan seksi yang ada pada Kantor Kecamatan Nongsa Kota Batam mempunyai peranan masing-masing, sesuai dengan tugas pokok, fungsi dan wewenang serta tanggung jawab yang telah ditentukan. Adapun kompensasi yang diberikan misalnya pada saat pegawai menjalankan tugas di luar daerah. Pegawai akan diberikan uang perjalanan dinas, akomodasi, konsumsi dan bentuk kompensasi lainnya. 
Gambar 1 Contoh Tugas dan Tanggung Jawab yang dilaksanakan Pegawai Kecamatan Nongsa
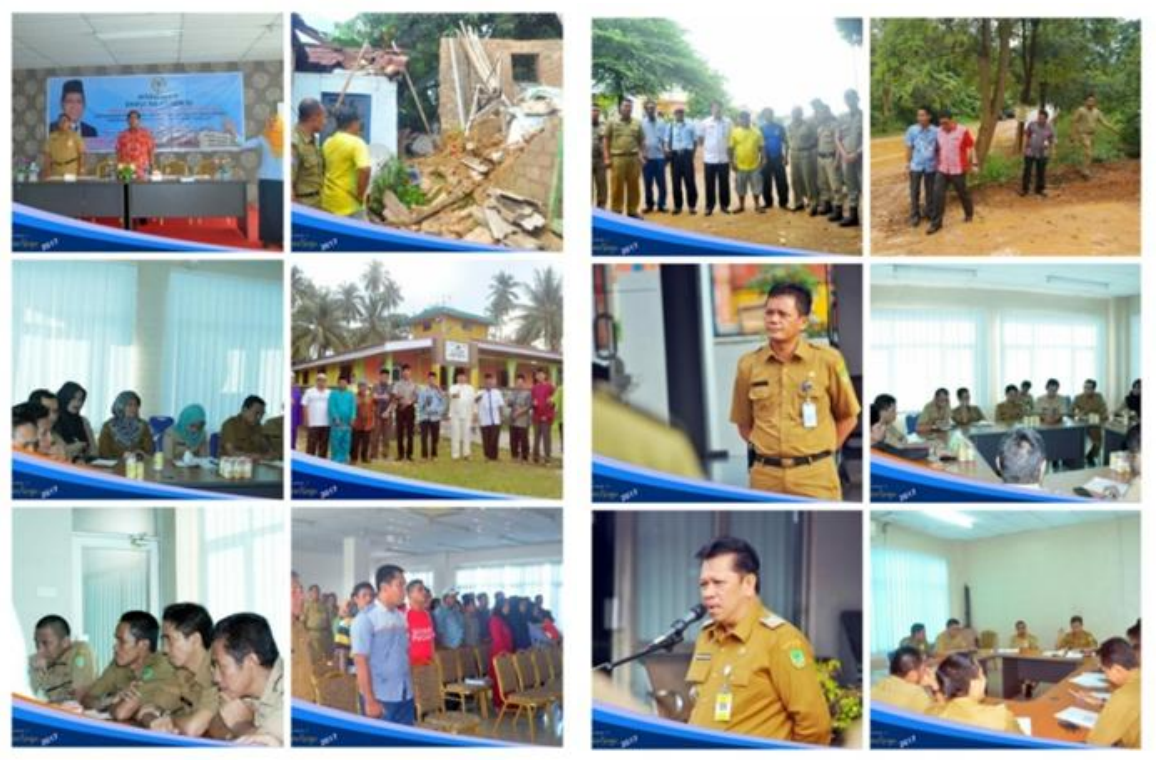

Sumber: Kecamatan Nongsa 2017

\section{Jabatan}

Kenaikan pangkat pada hakikatnya adalah penghargaan yang diberikan atas prestasi dan pengabdiannya. Menggunakan sistem pemberian kompensasi berbasis jabatan tidak lagi menggunakan dasar pangkat (golongan). Melainkan menggunakan jabatan itu sendiri sebagai acuan.

Tabel 3 Jabatan Pegawai Kecamatan Nongsa

\begin{tabular}{|c|l|c|}
\hline No. & \multicolumn{1}{|c|}{ Jabatan } & Tunjangan Jabatan \\
\hline 1 & Camat & Rp. 1.260.000,- \\
\hline 2 & Sekretaris Camat & Rp. $980.000,-$ \\
\hline 3 & Kasubag Program dan Keuangan & Rp. 490.000,- \\
\hline 4 & Kasubag Umum dan Kepegawaian & Rp. 490.000,- \\
\hline 5 & Kasi Pemerintahan & Rp. 540.000,- \\
\hline 6 & Kasi Pelayanan Umum & Rp. 540.000,- \\
\hline 7 & Kasi Kesejeahteraan Rakyat & Rp. 540.000,- \\
\hline 8 & Kasi Ketentraman dan Ketertiban & Rp. 540.000,- \\
\hline 9 & Kasi Pembangunan \& Pemberdayaan Masy. & Rp. 540.000,- \\
\hline
\end{tabular}


Dari tabel di atas diketahui jelas perbedaannya. Jabatan menentukan besaran tunjangan yang akan diterima. Selain tunjangan tersebut, diketahui juga bahwa terdapat kompensasi lainnya yang akan diterima, seperti rumah dinas, kendaraan, ruang kantor, tempat parkir dan lainnya. Kenaikan jabatan tentu akan mampu meningkatkan kompensasinya. Semakin tinggi jabatan seseorang, maka semakin tinggi suatu jabatan, maka beban kerja dan tanggung jawab yang diembannya semakin besar dan semakin berat, sehingga perlu dihargai dengan kompensasi yang layak sesuai dengan beban dan tanggung jawab yang diembannya.

\section{Jenjang Kepangkatan (Golongan)}

Jenjang kepangkatan atau golongan juga menjadi faktor pertimbangan untuk menambah kompensasi yang diterima seseorang. Pemberian kompensasi yang didasarkan pada pangkat, golongan, dan lamanya kerja tentunya akan berpengaruh terhadap sikap kerja para pegawai. Berdasarkan penelitian diketahui bahwa penentuan gaji pokok PNS didasarkan pada Peraturan Pemerintah Republik Indonesia Nomor 30 Tahun 2015.

Dari penelitian di Kecamatan Nongsa diketahui terdapat 5 jenis kenaikan pangkat, yaitu:

1. Kenaikan Pangkat Reguler

2. Kenaikan Pangkat Pilihan

3. Kenaikan Pangkat Istimewa

4. Kenaikan Pangkat Pengabdian

5. Kenaikan Pangkat Anumerta

Berdasarkan hasil penelitian tersebut diketahui bahwa jenjang kepangkatan (golongan) berpengaruh terhadap pemberian kompensasi pada pegawai Negeri Sipil. Pada setiap jenjang kepangkatan (golongan), tentunya besaran kompensasi yang akan diterima juga akan berbeda. Namun, tidak berlaku pada pegawai honor di Kecamatan Nongsa. Karena tidak ada jenjang kepangkatan (golongan) pada pegawai honor. 


\section{Prestasi Kerja}

Kinerja merupakan prestasi kerja yang diperoleh seseorang dalam jangka waktu tertentu. Pegawai yang memiliki kinerja yang baik tentu akan memperoleh kompensasi yang baik. Begitu pula sebaliknya, dengan kompensasi yang sesuai, tentunya dapat meningkatkan semangat kerja pegawai.Prestasi kerja adalah hasil kerja yang dicapai pegawai pada satuan organisasi sesuai sasaran kerja pegawai dan perilaku kerja. Sasaran kerja itu adalah rencana kerja dan target yang akan dicapai seorang pegawai.

Dari faktor prestasi kerja, dari hasil wawancara diketahui bahwa salah satu bentuk kompensasinya berupa kenaikan pangkat. Kenaikan pangkatnya adalah kenaikan pangkat istimewa. Dikatakan kenaikan pangkat istimewa, karena kenaikan pangkat ini disebut kenaikan pangkat yang diberikan kepada PNS yang menunjukan prestasi kerja yang luar biasa baiknya. Selain kenaikan pangkat, disebut juga terdapat penghargaan lainnya untuk pegawai.

Dalam rangka pembinaan terhadap pegawai yang telah menunjukkan prestasi, kompetensi, kemampuan, kerjasama, memiliki moral dan akhlak yang baik dalam melaksanakan tugas maka perlu diberikan penghargaan. Misalnya pemilihan pegawai teladan, dan doorprize untuk meningkatkan semangat kerja pegawai di lingkungan Kecamatan Nongsa.

\section{Gambar 2 Pemberian Penghargaan Pada Pegawai Kecamatan Nongsa}

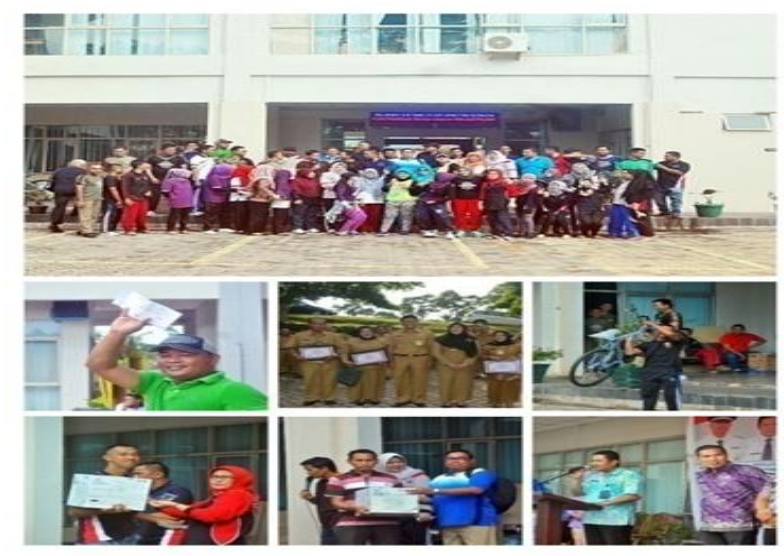


Berdasarkan hasil penelitian tersebut diketahui bahwa prestasi kerja berpengaruh terhadap pemberian kompensasi pada pegawai di Kecamatan Nongsa, baik pada PNS atau pegawai honor. Pada PNS dapat berupa kenaikan pangkatnya, pada pegawai honor dapat berupa bonus-bonus atau penghargaan lainnya. Semakin tinggi prestasi, semakin tinggi pula kompensasinya. Kompensasi diberikan melalui Bagian Program dan Keuangan, secara langsung dikirimkan ke rekening masingmasing pegawai Kecamatan Nongsa (non tunai). Sesuai yang telah dijelaskan sebelumnya bahwa kompensasi yang akan diterima adalah berdasarkan pekerjaan dan tanggung jawab yang telah mereka laksanakan.

Selama penelitian di Kecamatan Nongsa, peneliti mengamati sejauh mana faktor-faktor tersebut mempengaruhi pemberian kompensasi pada pegawai di Kecamatan Nongsa. Pegawai Negeri Sipil maupun Pegawai Honorer menyatakan jelas bahwa tentunya mereka akan mendapatkan kompensasi setelah melaksanakan tugas dan tanggungjawabnya. Selain itu, tingkat kesejahteraan pegawai menunjukkan bahwa sangat mempengaruhi kinerja dan perilaku pegawai.

Setiap bagian dan seksi yang ada pada Kantor Kecamatan Nongsa Kota Batam mempunyai peranan masing-masing, sesuai dengan tugas pokok, fungsi dan wewenang serta tanggung jawab yang telah ditentukan sebelumnya.Kepala Sub Bagian Umum dan Kepegawaian Kecamatan Nongsa menjelaskan bahwa tentunya terdapat perbedaan pemberian kompensasi antara Pegawai Negeri Sipil dan Pegawai Honorer, misalnya dalam hal komponen gaji.Berdasarkan penelitian di Kecamatan Nongsa, diketahui bahwa komponen gaji yang diterima PNS terdiri dari:

\section{Gaji Pokok}

Gaji pokok dibayarkan kepada pegawai secara berkala setiap bulan selama yang bersangkutan bekerja sebagai seorang PNS.

2. Tunjangan Keluarga bagi yang sudah menikah, yaitu:

a. Tunjangan suami atau istri

b. Tunjangan anak 
3. Tunjangan Perubahan Penghasilan, yaitu:
a. Tunjangan Umum
b. Tambahan Tunjangan Umum

4. Tunjangan Jabatan, yaitu:
a. Tunjangan Jabatan Sturuktural
b. Tunjangan Jabatan Fungsional
c. Pembulatan
d. Tunjangan Desa Terpencil

5. Tunjangan Beras

6. Tunjangan Khusus Pajak

Tunjangan untuk pemotongan pajak atas penghasilan yang didapatkan oleh PNS, baik yang masih aktif kerja ataupun yang telah memasuki masa pensiun.

7. Iuran Wajib Pajak (IWP) Iuran Wajib Pegawai (IWP) dipotong secara otomatis dari jumlah keseluruhan gaji dengan besaran 10\%. Potongan tersebut akan dibagi-bagikan untuk persiapan pemenuhan PNS, baik yang dirasakan sekarang atau nanti setelah memasuki masa pensiun.

\section{Taperum (Tabungan Perumahan PNS)}

Program yang disediakan oleh pemerintah untuk mempersiapkan pegawai dalam memiliki rumah.

\section{KESIMPULAN}

Terkait dengan faktor-faktor yang mempengaruhi pemberian kompensasi, berdasarkan hasil penelitian diketahui bahwa kompensasi merupakan hal yang sangat penting. Setiap bagian dan seksi yang ada pada Kantor Kecamatan Nongsa Kota Batam mempunyai peranan masing-masing, sesuai dengan tugas pokok, fungsi dan wewenang serta tanggung jawab yang telah ditentukan sebelumnya dan saling bekerjasama dalam menciptakan sumber daya manusia untuk mencapai tujuan organisasi pemerintahan agar terus berkembang. Sub Bagian Umum dan Kepegawaian bertugas dan 
bertanggung jawab dalam penyelenggaraan administrasi umum dan administrasi kepegawaian di Kecamatan Nongsa.

Berdasarkan hasil observasi dan wawancara yang telah peneliti lakukan pada kantor Kecamatan Nongsa, diketahui bahwa terdapat 6 faktor yang mempengaruhi pemberian kompensasi, yaitu pendidikan, pengalaman, beban pekerjaan dan tanggung jawab, jabatan, jenjang kepangkatan (golongan), dan prestasi kerja. Namun, pada pegawai Kecamatan Nongsa hanya terdapat 5 faktor yang mempengaruhi pemberian kompensasi, yaitu:

\section{Pendidikan}

2. Beban pekerjaan dan tanggung jawab

3. Jabatan

4. Jenjang kepangkatan (golongan)

5. Prestasi kerja

Dari hasil peneltian, diketahui bahwa pengalaman tidak termasuk dalam faktor yang mempengaruhi pemberian kompensasi pada pegawai Kecamatan Nongsa. Pengalaman dinyatakan lebih tepat untuk perusahaan swasta. Terdapat perbedaan pemberian Kompensasi antara Pegawai Negeri Sipil dan Pegawai Honorer. Pada Pegawai Negeri Sipil, dalam menentukan pemberian kompensasi yang akan diterima, dinyatakan bahwa faktor yang paling mempengaruhi yaitu jabatan dan jenjang kepangkatan (golongan). Melalui tingkatan tersebut dapat menentukan tingkat kesulitan, tanggung jawab, dampak, kualifikasi pekerjaan yang digunakan sebagai dasar pengaturan kompensasi, terutama jelas perbedaannya dalam hal penggajian. Pada Pegawai honorer, dalam menentukan kompensasi tidak terdapat aturan yang mengikat. Kompensasi yang akan diterima adalah berdasarkan pekerjaan dan tanggung jawab yang telah mereka laksanakan, berupa gaji dan jaminan kesehatan.

\section{REFERENSI}

Hasibuan, Malayu S.P. 2014. Manajemen Sumber Daya Manusia (Edisi Revisi). Jakarta: Bumi Aksara. 
Kasmir. 2016. Manajemen Sumber Daya Manusia (Teori dan Praktik). Jakarta: Rajawali Pers.

PB, Triton. 2005. Paradigma Baru Manajamen Sumber Daya Manusia. Nyutran MG II/1466: Tugu Publisher.

PB, Triton. 2010. Manajemen Sumber Daya Manusia Perspektif Partnership dan Kolektivitas. Nyutran MG II/1466: ORYZA.

Priansa, Donni Juan. 2016. Perencanaan \& Pengembangan SDM. Bandung: Alfabeta.

Satori, Djam'an dan Aan Komariah. 2010. Metodologi Penelitian Kualitatatif. Bandung: Alfabeta.

Siagian, Sondang P. 2015. Manajemen Sumber Daya Manusia. Jakarta: Bumi Aksara. Yani, H.M. 2012. Manajemen Sumber Daya Manusia. Jakarta: Mitra Wacana Media.

Profil Kecamatan Nongsa. http://skpd.batamkota.go.id/nongsa/tentang-kami-2/.

Undang-Undang yang mengatur Aparatur Sipil Negara (ASN) dan Pegawai Negeri

Sipil (PNS).http://www.asn-id.org/p/undang-undang-aparatur-sipil-negara.html.

Undang-Undang Republik Indonesia Nomor 5 Tahun 2014 Tentang Aparatur Sipil Negara.

Kota Batam dalam Angka 2016.

https://batamkota.bps.go.id/website/pdf_publikasi/Kota-Batam-Dalam-Angka2016.pdf.

Statistik Daerah Kecamatan Nongsa 2016.

https://batamkota.bps.go.id/website/pdf_publikasi/Statistik-Kecamatan-Nongsa2016.pdf.

Peraturan Pemerintah Republik Indonesia Nomor 19 Tentang Kecamatan. http://www.bpn.go.id/Publikasi/PeraturanPerundangan/PeraturanPemerintah/pe raturan-pemerintah-nomor-19-tahun-2008-1142.

Undang-Undang Republik Indonesia Nomor 23 Tahun 2014 Tentang Pemerintahan Daerah.http://www.bpn.go.id/Publikasi/Peraturan-Perundangan/UndangUndang/undang-undang-nomor-23-tahun-2014-4893. 
DIMENSI, VOL. 8, NO. $1: 127-141$

MARET 2019

ISSN: 2085-9996

Peraturan Walikota Batam Nomor 63 Tahun 2012 Tentang Uraian Tugas Pokok dan

Fungsi Kecamatan dan Kelurahan Kota Batam.

http://jdih.batam.go.id/perwako-2012.html.

Profil Kecamatan Nongsa Tahun 2016. 